\title{
Learning Music Entrepreneurship by Doing: How to Develop Experiential Learning Opportunities in an Academic Setting
}

\author{
Fabiana Claure \\ University of North Texas
}

This paper was presented at the 2018 International Summit of the

Music \& Entertainment Industry Educators Association

March 22-24, 2018

https://doi.org/10.25101/18.17

\section{Abstract}

An integral part of teaching music entrepreneurship involves helping students learn through experiential opportunities. Entrepreneurship, just like music, is best learned through practice and experience. In order to successfully implement hands-on learning opportunities, a few questions arise: how can we effectively create these experiences for our students outside of the classroom? How can we build student engagement and participation in non-required events? Students are very busy with their required academic coursework and other activities. Capturing their attention and getting them involved in non-required events can be a challenge.

Using the model the author created and implemented at the University of North Texas College of Music's Career Development and Entrepreneurship in Music Programrecognized among the Top 15 Best Music Business Schools by Billboard Magazine in 2017 and 2018 - this paper will provide an overview of the various types of experiential learning initiatives that can be launched in an academic setting. It will also describe common challenges and potential solutions to take into consideration while launching these initiatives.

Keywords: music entrepreneurship, music business school, music business plan, marketing, music industry, experiential learning, internship, competition, Denton, Dallas-Fort Worth, Texas, University of North Texas, College of Music, Fabiana Claure

\section{Introduction}

Experiential learning allows students to develop skills in an active way using real-life scenarios. This learning model encourages them to go beyond what is expected of them from an academic standpoint and make the effort to explore extracurricular opportunities. Because the music industry is constantly evolving, we must teach our students to adapt to the changing trends in business. The experiential learning opportunities that were offered to me while I was pursuing my graduate studies ignited my entrepreneurial spirit, leading me to successfully launch my own business a few months after earning my Doctor of Musical Arts degree at the University of Miami. ${ }^{1}$ My own career proves the value of experiential learning opportunities.

Music business schools can incorporate experiential learning not only through internship opportunities and class projects, but also by creating program initiatives with a business incubator approach, helping students launch their businesses while in school. Some of the most established businesses in today's world, such as Facebook, FedEx, Google, Yahoo, WordPress, and Time Magazine, were created by college students. No matter how overwhelmed students may seem with academic requirements, the opportunities for students to launch a business while in school are vast. They have access to faculty mentors, peers, funding opportunities, university facilities, and more. Encouraging and mentoring students to create a music business plan and launch their businesses on a manageable scale or with the minimum viable product or service can lead to outstanding results.

\section{Laying the Groundwork for Experiential Learning Opportunities}

In 2016, I was appointed Director of Career Development and Entrepreneurship in Music at the University of North Texas College of Music. In this role, I was tasked with laying the groundwork for developing the music entrepreneurship program at UNT. Using the market research strategies that helped me create my own business, Superior Academy 
of Music, in Miami, ${ }^{2}$ I investigated ways to create experiential learning opportunities that would strengthen our program. The research strategies I used included studying the program's existing resources and offerings; reaching out to the various departments within the College of Music to learn what opportunities were available to students; exploring ways to collaborate with faculty and staff; and meeting with the staff in charge of marketing and communications, as well as with fundraising and development officers.

In addition to partnering with faculty and staff, I researched student attitudes toward music entrepreneurship. To build an effective program, our team needed to find out what students hoped to gain from the existing program offerings and what additional entrepreneurial skills and concepts they wished to learn. Though our program already offered music entrepreneurship coursework, students' responses to surveys revealed that the potential impact of our entrepreneurship program was limited because not all students had the space in their degree programs to register for these classes. It became clear that more students would benefit if we offered opportunities to develop entrepreneurial skills outside the classroom.

\section{Music Entrepreneurship Competition}

Our program needed an entrepreneurial initiative that would have a wide reach and offer opportunities to all the College of Music students. I decided to create a Music Entrepreneurship Competition. ${ }^{3}$ An interdepartmental advisory committee formed under my directorship, bringing together faculty members from the College of Music and the College of Business. Administrators from the College of Music approved my request for funding for the initiative. Their enthusiastic and generous support allowed our program to hold its inaugural competition in 2017.

The purpose of this competition was to promote student engagement, innovation, and entrepreneurial thinking. Students prepared music business plans utilizing a variety of resources that were created and/or compiled for them. In addition to our existing entrepreneurship courses, ${ }^{4}$ these resources included online business plan writing workshops and articles, ${ }^{5}$ as well as faculty mentorship. With almost 1,600 students in our program, we knew it would be challenging to inform them about the new experiential learning opportunity and motivate them to participate in the competition. To overcome this obstacle, I created three workshops that helped students further explore the various steps and skills needed to create a music business plan. These workshops allowed smaller groups of students to meet with me and receive in-depth guidance prior to entering the competition. This personal outreach encouraged students to participate, and has therefore been key to the success of the initiative.
We have now hosted two yearly editions of this competition and the outcomes have been outstanding. UNT's College of Music has awarded nearly $\$ 20,000$ in cash prizes each year to help the winning teams launch their businesses. The competition has also brought our students success outside of the College of Music. After our inaugural competition, our music students went on to compete in the UNT College of Business's Westheimer New Venture Challenge. ${ }^{6}$ Out of twelve finalists selected university-wide, four were music students. One of these students earned the $\$ 5,000$ second-place prize, while another raised $\$ 5,000$ from two of the competition judges who were incredibly moved by the student's business plan. ${ }^{7}$ Since the launch of the entrepreneurship program and music entrepreneurship competition, we have helped launch over a dozen student-led businesses. ${ }^{8}$

\section{Internships, External Partnerships, and Off- Campus Performance Opportunities}

UNT is a thriving community with many on-campus opportunities for students. Yet students also need to build connections with the outside professional world so they can develop business skills in addition to the academic skills they hone in their classes. To meet this need, I established an internship program by reaching out to local music and arts organizations and inquiring about potential interest in working with our UNT music students as interns. ${ }^{9}$ The organizations responded positively and we quickly established internship opportunities in the Dallas-Fort Worth (DFW) area music scene. Several of the students who worked with these organizations as interns were later hired to continue working as paid employees. A couple of them were even invited to join the Board of Directors of one of the local symphony orchestras. ${ }^{10}$

In addition to giving students opportunities to work for established businesses, a thriving music entrepreneurship program should help students develop their own business initiatives. Developing community partnerships has been an essential part of my role as the director of our entrepreneurship program. A local business incubator program called Stoke Denton opened its doors during the fall of 2016, providing an opportunity for our students to work with professionals from a variety of backgrounds. ${ }^{11}$ By reaching out and describing our UNT music entrepreneurship program, I was able to establish a student-membership opportunity for UNT students to work with these mentors. Working with the Stoke coaches, several of our students successfully launched local businesses.

Performing in off-campus venues is another important opportunity for students to seek. Students work hard to prepare their degree recitals, but sometimes these concerts end up being attended only by their grading committee and a few peers. To solve this problem, I created a database of 
off-campus performance venues, ${ }^{12}$ which includes a variety of free and low-cost locations. The database makes it simple for students to find locations where they can showcase their degree recitals either as pre-recital run-throughs, or after their degree recital has passed. Several students have made arrangements to perform their degree recitals off campus and in this way, their music has reached a larger audience.

\section{Strategies for Overcoming Challenges}

Getting the word out about our new initiatives has been the most consistent challenge we have faced. Students find it difficult to take part in extracurricular programs when they are overwhelmed and mostly concerned with their academic coursework. However, music business programs can overcome this obstacle using the same marketing techniques that they aim to teach their students. To get students engaged with our new program offerings, I employed many of the same tactics that I had formerly used to attract clients to my music school in Miami. During faculty meetings, I reached out to colleagues and shared with them the latest initiatives so they could help spread the word among their students. I also generated awareness by creating a website for the program. ${ }^{13}$ The site included, among other things, a variety of videos with interviews featuring our music entrepreneurs sharing their stories and successes. ${ }^{14}$ Students are inspired by hearing their peers speak about their experiences while taking advantage of our program's offerings. In addition to having our own website, we also post content regularly on Facebook, ${ }^{15}$ Instagram, ${ }^{16}$ and YouTube. ${ }^{17}$ Our strong social media presence has increased our reach within the online community. For example, we have used Facebook to live-stream several of our events and even allowed local and virtual audience members to vote for their favorite teams during our competitions.

\section{Innovative Music Programming Competition}

As part of the initiatives launched during our second year (2017-2018), I created another competition called the Innovative Music Programming Competition. ${ }^{18}$ This initiative was designed to encourage students to create compelling and interactive musical programs that engage audiences, cross musical genres, foster interdisciplinary collaborations, and push boundaries. The winners of this competition earned the opportunity to perform off-campus at the Greater Denton Arts Council and received a $\$ 250$ award to promote the concert and attract an audience. ${ }^{19}$ They were also featured on UNT's social media pages. As part of the competition application, students had to not only describe how their intended program was innovative and unique, but also how they would be able to attract an audience for the off-campus concert. ${ }^{20}$ In this way, a hands-on entrepreneurial and marketing learning component was added to the musical creativity component of the competition.

\section{Music Entrepreneurship Departmentals}

In an effort to create a regular bi-weekly meeting opportunity that would provide a forum for all our music entrepreneurship students to come together, I launched our Music Entrepreneurship Departmentals. ${ }^{21}$ These forums offered students the opportunity to meet professionals in the music industry and ask them questions. We hosted fourteen departmentals during the 2017-2018 academic year and all the guest presentations were added to our YouTube library for easy access and later viewing. In addition to hosting guest speakers, we also took advantage of this platform to participate in the Global Entrepreneurship Week event, ${ }^{22}$ in which students got the opportunity to pitch their business plans live on Facebook. ${ }^{23}$

\section{Student Artists Entrepreneurs}

Another initiative of the second year was the creation of a UNT Student Artists Entrepreneur (SAE) student organization. ${ }^{24}$ Even though SAE originated at the College of Music, the purpose was to integrate student entrepreneurs from the entire campus, thus allowing students to develop leadership skills, form relationships, and initiate further entrepreneurial endeavors both on and off campus. Students met regularly throughout the year and presented an off-campus event hosted at the Greater Denton Arts Council. During this event, SAE members showcased their student-led businesses and invited local arts entrepreneurs to present their businesses. They also organized a networking event after the business showcases to develop closer relationships with established arts entrepreneurs in Denton. ${ }^{25}$

\section{Marketing and Promotion Strategies}

Throughout all of these program initiatives, I worked to spread the word not only within UNT, but also to surrounding communities. An important strategy to achieve this was to work closely with the university's communications office and make sure they were always in the loop regarding our program's news and successes. As a result, our program received significant press coverage early on, including several television interviews, featured newspaper articles, local blogs, and a radio interview. This press coverage is compiled on our website so that visitors to the site can learn more about our program's community profile. ${ }^{26}$ Our robust media presence has helped build the program's credibility and expand its visibility across the DFW area and beyond.

After only one year, the UNT Music Entrepreneurship program gained national acclaim as one of Billboard's Top 15 Music Business Schools in 2017. ${ }^{27}$ This was an incredible highlight for our new program and granted us visibility and recognition within the university and nationally. The following year, UNT's Music Entrepreneurship program was once again recognized in Billboard's 2018 Top Music Business Schools. ${ }^{28}$ This media attention demonstrates that 
community outreach, online networking, and student and faculty engagement can dramatically raise the profile of a music business program.

\section{Conclusion}

Throughout the creation of all these initiatives, there have been great success stories as well as significant challenges. Promoting student engagement has been a constant hurdle to overcome every time a new initiative is launched. Promoting self-motivation by creating experiential learning opportunities open to everyone has been key to building engagement. The success of our program is demonstrated by the number of students who have utilized our online resources to prepare their music business plans on their own, without being enrolled in any of the existing music entrepreneurship courses. On the other hand, there are some students who have created full-fledged business plans as part of their course requirements but have hesitated or decided not to take part in our non-required initiatives, such as the music entrepreneurship competition. As such, our entrepreneurship program's experiential learning opportunities are a supplement and complement to our coursework, not a replacement.

When it comes to generating awareness of new entrepreneurship program initiatives, there is no one-size-fits-all approach. Listening to student and faculty input is imperative in order to gauge the best strategies for creating and promoting experiential learning opportunities. Rather than spreading the word about our program offerings via email blasts, which are often ignored by students, we depend on face-toface interaction to raise awareness. My team and I visit the various instrumental, composition, jazz studies, and voice departmentals every semester to discuss all the program offerings with students, and I have personally connected with faculty during our regular meetings to talk about the entrepreneurship program.

One of the most important things we have done to promote our entrepreneurial initiatives has been clearly communicating the benefits to students and faculty. Students are particularly motivated by stories of peers who have launched their own businesses while in school. Additionally, to ensure the long-term success of our program, we consistently assess how to improve our initiatives and outreach efforts. By measuring our program's effectiveness and reflecting on results, we ensure that our students can continue to engage with and benefit from the program offerings. Many of the same principles that we teach our students regarding entrepreneurship - such as being innovative, being a good marketer, listening to customer feedback, and finding ways to stand out - are the same ones I recommend applying while launching and developing experiential learning opportunities in an academic setting.
Note from the author: Interested readers will find additional information in a September 28, 2018 article entitled "Business of Music: College of Music Graduates Hone Their Craft With Entrepreneurial Spirit" in the UNT North Texan magazine.

\section{Endnotes}

1. Fabiana Claure, "Entrepreneurship," http://fabianaclaure.com/entrepreneurship.htm.

2. "Superior Academy of Music," https://superioracademyofmusic.com/.

3. "Music Entrepreneurship Competition," http://career. music.unt.edu/competitions/entrepreneurship.

4. "Graduate Courses," http://career.music.unt.edu/graduate-courses.

5. "Competition Resources," http://career.music.unt.edu/ competition/resources.

6. "Westheimer New Venture Competition," https://cob. unt.edu/westcomp.

7. "College of Music students win prize and raise funds for business," https://www.facebook.com/ media/set/?set $=$ a.449453538725477.1073741831. 351739168496915\&type $=1 \& \mathrm{l}=1 \mathrm{~d} 2 \mathrm{a} 9$ fecc 2 .

8. "Music Entrepreneurship at the University of North Texas, Fall 2017 Newsletter," http://career.music. unt.edu/sites/default/files/ME_Newsletter_December_2017.pdf. 
9. “Internships,” http://career.music.unt.edu/internships.

10. "Music Entrepreneurship at the University of North Texas, Spring 2018 Newsletter," https://drive.google. com/file/d/18Tnwo2zmt2hxI1CiwOjfSdkAzYjBeuo / view.

11. Stoke, https://stokedenton.com/.

12. "Off-Campus Performance Opportunities for UNT Students," http://career.music.unt.edu/performance-opportunities.

13. "Career Development and Entrepreneurship in Music," http://career.music.unt.edu/.

14. "UNT Music Entrepreneurs," http://career.music.unt. edu/student-businesses.

15. "UNT Career Development and Entrepreneurship in Music," https://www.facebook.com/UNTMusicEntrepreneurship/.

16. UNT Music Entrepreneurship. https://www.instagram. com/untmusicentrepreneurship/.

17. "UNT Music Entrepreneurship," https://www.youtube. com/channel/UCaNf3UU2kURHASx 5uLon42g.

18. "Innovative Music Programming Competition," http:// career.music.unt.edu/competition/innovative-music-programming.

19. "Greater Denton Arts Council," https://dentonarts. com/.

20. UNT Music Entrepreneurship, "Innovating Music Program Competition," (video), https://www.youtube. com/watch?v=01B7XcBYv4Q.

21. "Departmentals," http://career.music.unt.edu/departmentals.

22. "Global Entrepreneurship Week," https://genglobal. org/gew.

23. "Global Entrepreneurship Business Pitches," (video), https://www.facebook.com/UNTMusicEntrepreneurship/videos/537416993262464/.

24. "Student Artist Entrepreneurs," http://career.music.unt. edu/sae.

25. "UNT Student Artists Entrepreneurs Business Showcase at GDAC" (video), https://www. facebook.com/UNTMusicEntrepreneurship/videos/632092980461531/.

26. "Press," http://career.music.unt.edu/press.

27. Cathy Applefeld Olson and Thom Duffy, "The 15 Best Music Business Schools in 2017," https://www.billboard.com/articles/news/magazine-feature/7965559/ best-music-business-schools-2017.

28. Thom Duffy, "Bonnaru U? Billboard's 2018 Top Music Business Schools," https://www.billboard.com/ articles/business/8463104/top-music-business-schools2018-billboard.

\section{References}

"Career Development and Entrepreneurship in Music." University of North Texas College of Music. http:// career.music.unt.edu/.

Claure, Fabiana. "Entrepreneurship." FabianaClaure.com. http://fabianaclaure.com/entrepreneurship.htm.

"College of Music students win prize and raise funds for business." UNT Career Development and Entrepreneurship in Music. https://www.facebook.com/ $\underline{\text { media/set/?set }=\text { a.449453538725477.1073741831. }}$ 351739168496915\&type $=1 \& \mathrm{l}=1 \mathrm{~d} 2 \mathrm{a} 9$ fecc 2 .

“Competition Resources." Career Development and Entrepreneurship in Music. University of North Texas College of Music. http://career.music.unt.edu/competition/resources.

"Departmentals." Career Development and Entrepreneurship in Music. University of North Texas College of Music. http://career.music.unt.edu/departmentals.

Duffy, Thom. "Bonnaru U? Billboard's 2018 Top Music Business Schools." Billboard. June, 29. 2018. Accessed September 12th, 2018. https://www.billboard. com/articles/business/8463104/top-music-businessschools-2018-billboard.

"Global Entrepreneurship Business Pitches" (video). YouTube. November 15, 2017. Accessed June 25, 2018. https://www.facebook.com/UNTMusicEntrepreneurship/videos/537416993262464/.

"Global Entrepreneurship Week." Global Entrepreneurship Network. Accessed June 25, 2018. https://genglobal. org/gew.

"Graduate Courses." Career Development and Entrepreneurship in Music. University of North Texas College of Music. http://career.music.unt.edu/graduate-courses.

“Greater Denton Arts Council." DentonArts.com. https:// dentonarts.com/.

"Innovative Music Programming Competition." Career Development and Entrepreneurship in Music. University of North Texas College of Music. http://career. music.unt.edu/competition/innovative-music-programming.

"Internships." Career Development and Entrepreneurship in Music. University of North Texas College of Music. http://career.music.unt.edu/internships.

Music Entrepreneurship at the University of North Texas, Fall 2017 Newsletter. University of North Texas College of Music. December 2017. http://career.music. unt.edu/sites/default/files/ME Newsletter_December_2017.pdf.

Music Entrepreneurship at the University of North Texas, Spring 2018 Newsletter. University of North Texas College of Music. https://drive.google.com/file/d/18Tnwo2zmt2hxI1CiwOjfSdkAzYjBeuo/view. 
"Music Entrepreneurship Competition." Career Development and Entrepreneurship in Music. University of North Texas College of Music. http://career.music.unt. edu/competitions/entrepreneurship.

"Off-Campus Performance Opportunities for UNT Students." Career Development and Entrepreneurship in Music. University of North Texas College of Music. http://career.music.unt.edu/performance-opportunities.

Olson, Cathy Applefeld, and Thom Duffy. "The 15 Best Music Business Schools in 2017." Billboard. September 18, 2017. Accessed June 25, 2018. https:// www.billboard.com/articles/news/magazine-feature/7965559/best-music-business-schools-2017.

"Press." Career Development and Entrepreneurship in Music. University of North Texas College of Music. Last modified April 25, 2018. Accessed June 26, 2018. http://career.music.unt.edu/press.

Stoke. https://stokedenton.com/.

"Student Artist Entrepreneurs." Career Development and Entrepreneurship in Music. University of North Texas College of Music. http://career.music.unt.edu/sae.

"Superior Academy of Music." Superior Academy of Music. https://superioracademyofmusic.com/.

UNT Career Development and Entrepreneurship in Music. Facebook. Last modified June 24, 2018. Accessed June 26, 2018. https://www.facebook.com/UNTMusicEntrepreneurship/.

"UNT Music Entrepreneurs." Career Development and Entrepreneurship in Music. University of North Texas College of Music. http://career.music.unt.edu/student-businesses.

UNT Music Entrepreneurship. "Innovating Music Program Competition" (video). YouTube. December 18, 2017. Accessed June 25, 2018. https://www.youtube.com/ watch?v=01B7XcBYv4Q.

"UNT Music Entrepreneurship." Instagram. Last modified June 24, 2018. Accessed June 26, 2018. https://www. instagram.com/untmusicentrepreneurship/.

"UNT Music Entrepreneurship." YouTube. Last modified May 3, 2018. Accessed June 26, 2018. https://www. youtube.com/channel/UCaNf3UU2kURHASx 5uLon $42 \mathrm{~g}$.

"UNT Student Artists Entrepreneurs Business Showcase at GDAC" (video). Facebook. May 24, 2018. Accessed June 25, 2018. https://www.facebook.com/UNTMusicEntrepreneurship/videos/632092980461531/.

"Westheimer New Venture Competition." College of Business. University of North Texas College of Business. https://cob.unt.edu/westcomp.

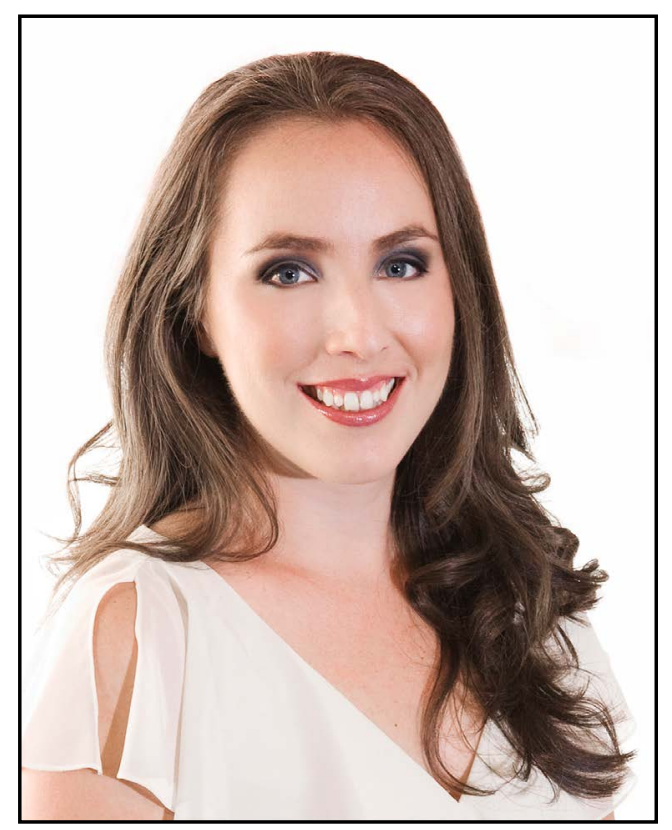

Fabiana Claure is a multifaceted concert pianist, educator, administrator, and entrepreneur. Her diverse musical career and successful business experience, as well as her international background-having lived in the U.S., Bolivia, and Cuba - have allowed her to gain an empowering and global perspective towards music and entrepreneurship education. Fabiana is the Director of Career Development and Entrepreneurship in Music at the University of North Texas where she is spearheading the creation of the music entrepreneurship program. Since her arrival to UNT, she has founded several initiatives including the Music Entrepreneurship Competition, the Innovative Music Programming Competition, a bi-weekly departmental, a student artist entrepreneur organization, and an internship program. Several of her UNT students have gone on to raise start-up funds and create successful music businesses while in school. After only one year since its launch, the UNT College of Music entrepreneurship program earned national recognition being ranked among the Top 15 Music Business Schools in 2017 and again in 2018 by Billboard magazine.

Fabiana is also the Co-Founder and Executive Director of Superior Academy of Music (SAM) in Miami. Her academy has been featured twice on national television (PBS). SAM's students have won full-tuition university scholarships, local and state certificates of excellence, and have been selected to perform at Carnegie Hall. Fabiana is an active concert pianist and an internationally certified examiner for the Royal Conservatory of Music. She has performed in the U.S., Bolivia, Cuba, and Spain, where she has been featured as a soloist with orchestras and also as a duo-pianist, along with her husband, pianist William Villaverde. Her CD, "Fabiana Claure, Debut Album" was commercially released in 2013. Fabiana has been a featured speaker at the 
Music and Entertainment Industry Educators Association Summit, the Network for Music Career Development Officers Conference, and the Music Biz conference organized by the Music Business Association. Her prior work includes being the Royal Conservatory of Music's Regional Associate for the state of Florida where she created an extensive network of teachers and executed national strategies, acting as the key spokesperson and representative for the Royal Conservatory.

Fabiana is a member of the College Music Society, the Music and Entertainment Industry Educators Association (MEIEA), the Music Business Association, the Pi Kappa Lambda National Music Honor Society, the Society for Arts Entrepreneurship Education (SAEE), and the Recording Academy(GRAMMYs). She also serves as an advisory board member for the UNT Murphy Center for Entrepreneurship and as a treasurer for the Pi Kappa Lambda Music Honor Society Alpha Alpha chapter. Fabiana holds a Doctor of Musical Arts in Piano Performance degree with cognates in Music Business and Entertainment Industries from the University of Miami. For more information, visit: www.fabianaclaure.com. 


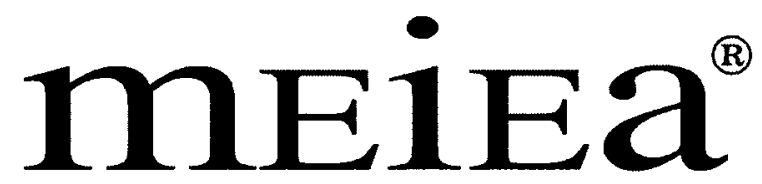

MUSIC \& ENTERTAINMENT INDUSTRY

EDUCATORS ASSOCIATION

\section{PROCEEDINGS OF THE \\ 2018 INTERNATIONAL SUMMIT}

OF THE

\section{MUSIC \& ENTERTAINMENT INDUSTRY EDUCATORS \\ ASSOCIATION}
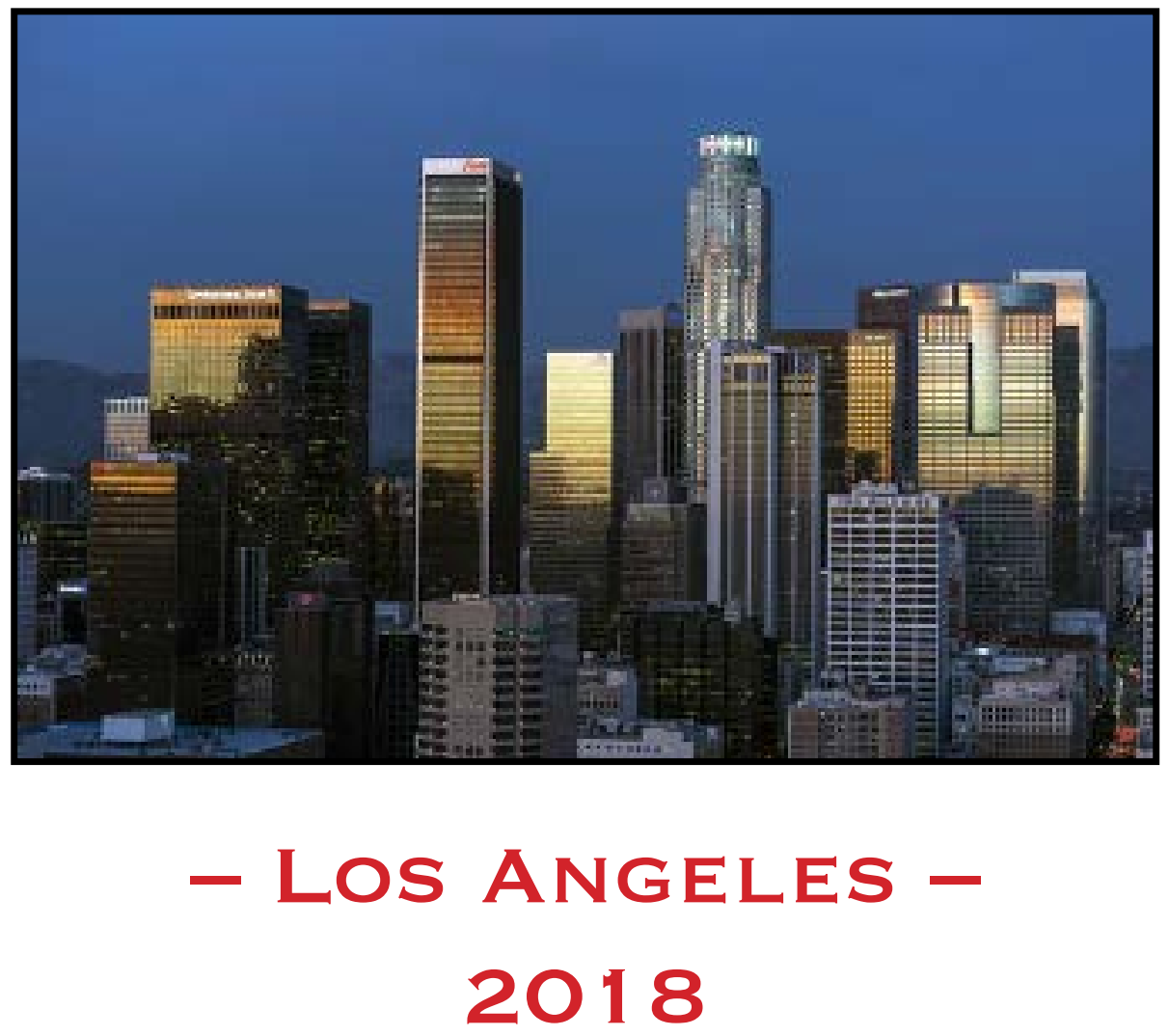

March 22 - 24, $2018 \cdot$ Embassy Suites by Hilton - Los Angeles/Glendale 